\title{
The Proposed German Penal Code
}

$\mathrm{T}$

HE German Code, the Bürgerliches Gesetzbuch of 1900, was exclusively civil. The criminal law was left in concededly provisional form in which it was put at the time of the creation of the German Empire in 1870. The great strides made in Germany in the study of crime and punishment would have necessitated a revision, even without the profound changes caused by the war and the establishment of the Republic. One of the first tasks which the new Ministry of Justice set before itself was the reform of the criminal law. In 1922, the first official draft was published. It attempted to embody not merely the ideas of von Liszt but in a general way to incorporate the spirit of modern criminological investigation to which Germany may well claim to have contributed more than any other single nation with the exception of Italy.

T'wo things characterized the original draft-the complete abandonment of the retributive view of punishment and the substitution for it of a theory which sees in punishment a means of safeguarding society-of which society the criminal is part so far as he is capable of rehabilitation. The second thing was that punishment was fitted not to the crime but to the person of the criminal. A new type of criminal, the "conscientious" criminal (Überzeugungsverbrecher) was especially dealt with. Finally the incorrigible and mentally inferior criminal, who constituted a permanent danger to society, was to be, by judicial action, permanently segregated. Thus the three principles of von Liszt, deterring of the casual criminal, reformation where possible, segregation of incorrigibles, were to be given practical application.

The draft of 1922 was widely studied and commented on especially in the two conventions at Bonn and at Cologne in the summer of 1926 . However, by 1924 the draft had already been seriously modified. It has since that time been even more radically amended in the Upper House (Reichsrat) and its original sponsors as well as liberal opinion throughout Germany are bitterly disappointed in the form in which, it seems, it is to be presented to the Reichstag this yrear (1927).

The retributive character of punishment reappears, and with it, the penalizing of what are often accidental consequences of an act. The original draft treated attempt at crime and aid in its commission on a par with the crime itself. This point of view is abandoned. It may be stated that the revision of 1924 had already 
reintroduced the death penalty, the distinction between state's prison and penitentiary (Zuchthaus and Gefängnis) and the criminal punishment of sexual aberrations-all of which had been abolished by the original draft.

Only in one matter, in dealing with incorrigibles, does the present draft maintain the principles of the first one. Intensification of punishment is allowed here, but the essential point, that such persons, as well as irresponsible criminals, might be assigned by a court to an appropriate institution for cure or permanent seclusion, is omitted. Instead, such assignment is declared to be an administrative act, not within the court's competence. The result of this doctrinaire retrogression is that an irresponsible dangerous criminal must be acquitted in the hope that some other authority may intervene to protect society against him.

Conditional remission of sentence, which was general under the first draft, is limited in the new one to crimes punishable by imprisonment for not more than six months. This limitation deprives the principle of most of its importance. Similarly the doctrine, accepted in the first draft, that in determining pumishment, the court must take into account the effect of the special conditions under which the crime was committed, is reduced to a vagne permission to consider extenuating circumstances.

The first draft abolished loss of civic rights as a form of punishment. The present one re-establishes it. Tramps, prostitutes and beggars are once more added to the criminal classes, although in the original form of the code, they were assigned to workhouses or houses of correction. Neither change can be called an improvement.

Two changes with political inplications may be considered. The first draft provided that conscientious criminals were to be punished by a form of detention that adequately prevented the crime without involving degradation or punitive hardship on the criminal. In the new draft, this takes the form of a provision that in punishing a crime, the court may consider the fact that its motives were worthy of respect. Finally, preparation for treasonable acts and libel of the State are once more independent crimes.

In both these provisions, the liberals of Germany see a real danger. Existing sections of similar import have, it is asserted, been applied with such severity against radicals and such leniency against reactionaries, that confidence in this side of judicial activity has been seriously impaired. The existence of a lack of confidence 
was the subject of an agitated discussion throughout Germany during the last year, and was reluctantly admitted even by conservative leaders. The mass of the judiciary are men appointed under the old regime and are credited with only a qualified loyalty to republican institutions. Nor has the situation been improved by such grave judicial scandals as that of Magdeburg in the summer of 1.926 .

That the new draft in details constitutes an advance on the existing code may be admitted. But it is not an advance in principle or in spirit, and that is as regrettable in itself as it is discouraging to the men who have labored so hard to bring about a real penal reform.

It may be noted that the code, whatever its final form is to be, will be passed almost simultaneously in Germany and in Austria.*

Paris, France.

Max Radin.

*This brief resumé is derived from discussions carried on at the Juristentag which was held in Cologne in September, 1926, and, to a very large exterit, from the excellent article of Professor Gustav Radbruch in the Vossische Zeitung of May 10, 1927. Professor Radbruch was Minister of Justice in 1922 and had much to do with the issuance of the first draft. Use of his article is made with his permission. 